\title{
MUHAMMADIYAH DAN AGENDA GERAKAN UNTUK INDONESIA YANG BERADAB $^{1}$
}

\section{- M. Alfan Alfian}

Universitas Nasional (UNAS) Jakarta, Indonesia

Email: malfanalfian@gmail.com

\begin{abstract}
Abstrak
Paper ini adalah refleksi intelektual tentang Muhammadiyah dan kaitannya dengan agenda gerakan untuk Indonesia yang beradab. Tujuan utama dari pewacanaan masalah ini, sebagai upaya membangun gagasan alternatif untuk menjawab pelbagai fenomena krisis kemanusiaan yang telah menjangkiti bangsa ini. Tulisan yang terinspirasi dari buah permenungan artistik seorang cendekiawan, sastrawan dan tokoh bangsa terkemuka, HAMKA, membawa kepada suatu gagasan brilian yang menegaskan bahwa Muhammadiyah harus menjadi pelopor gerakan pemikiran inklusif. Dengan demikian, birokratisme yang kerap menjadi masalah bagi setiap institusi sosial keagamaan yang sudah mapan, tidak menjadi halangan untuk menebarkan nilai-nilai kebajikan universal tersebut.
\end{abstract}

Kata Kunci: Indonesia Beradab, Gerakan Sosial, Muhammadiyah, Inklusivisme

Tulisan ini dipresentasikan dalam "Tadarus Pemikiran Kaum Muda Muhammadiyah: Muhammadiyah dan Gerakan Sosial Baru” yang diselenggarakan oleh Universitas Muhammadiyah Malang bekerjasama dengan Jaringan Intelektual Muda Muhammadiyah, Malang 17-19 Juli 2014. 


\section{Pendahuluan}

Diribut runduklah padi

Dicupak datuk Temenggung

Hidup kalau tidak berbudi

Duduk tegak kemari canggung

Tegak rumah karena sendi

Runtuh budi rumah binasa

Sendi bangsa ialah budi

Runtuh budi runtuhlah bangsa

\section{Buya HAMKA (Lembaga Budi, 1940)}

Saya memulai makalah ini dengan mengomentari puisi Buya HAMKA, ulama Muhammadiyah yang populer pada zamannya. Bahwa kalimat, "Runtuh budi runtuhlah bangsa" di atas jelaslah suatu rumusan yang tampaknya tidak memerlukan penjelasan yang panjang lebar lagi - betapapun kalimat ini ditolak oleh mereka yang kurang suka hal-hal normatif. Mungkinkah "runtuh budi" dapat terjadi di negeri beragama atau yang mayoritas masyarakatnya beragama Islam? Jawabnya jelas: Mengapa tidak bisa? Banyaklah otokritik disampaikan oleh para ulama dan cendekiawan Muslim bahwa Indonesia yang mayoritas penduduknya Muslim ini, yang jumlah jamaah hajinya demikian besar dan nyaris selalu meningkat per tahun, yang umroh berkali-kali juga banyak, bahkan kalangan artis dan politisi sekalipun, tetapi yang korupsi juga banyak? Nyinyir sekali pertanyaan yang sedemikian itu. Jawaban ringkas versi HAMKA jelaslah sudah, karena budi sebagai sendi bangsa tengah rapuh, betapapun bangsa itu mayoritas penduduknya Muslim.

Apa yang disinggung di atas, dalam perbincangan dewasa ini, sudahlah melampaui soal-soal paham kebangsaan, bahkan hubungan agama (Islam) dan negara. Persoalan budi, kiranya melampaui semua itu. Tetapi, ketika HAMKA menyinggung soal bangsa (nation), tentulah yang dimaksud bangsa kita: Indonesia. HAMKA dan semua ulama Muhammadiyah lainnya, tentu para nasionalis, kendatipun sejarawan kerap memposisikan mereka sebagai nasionalis-santri yang berkompetisi dan juga bisa bermitra dengan para nasionalis-sekuler. Deliar Noer dalam tulisannya "HAMKA dan Sejarah", mencatat HAMKA sebagai "seorang 
ulama yang sejak awal sepakat dengan paham kebangsaan”. HAMKA berpendapat antara kebangsaan dengan Islam tidak perlu dipertentangkan, malah bisa sesuai. Deliar Noer mengungkapkan;

"Paham HAMKA seperti ini terbit ketika ia mulai melakukan studi tentang sejarah Indonesia dari sudut pandangan Islam. Ia mengakui juga betapa pentingnya sejarah Indonesia sebelum Islam tiba. Tetapi, katanya, masa tersebut telah memberikan tempat pada Islam yang memang telah membentuk dan membina sikap, perasaan dan pemikiran, serta tindakan dari mayoritas sekian banyak penduduknya."

Bagi HAMKA, iman adalah sumber kekuatan. Imbuauan yang disampaikan HAMKA dalam salah satu karya populernya Tasauf Modern berikut, merupakan bukti HAMKA ingin bangsanya merdeka, sebab dengan nikmat kemerdekaan itulah, ada jalan bahagia untuk memanjukan bangsa.

"Wahai orang-orang yang menyerukan kebenaran, yang berniat hendak memajukan bangsa dan tanah airnya. Wahai orang-orang yang tidak sayang darah dan nyawa untuk mencapai bahagia dan kemerdekaan, yang hendak melepaskan aniaya dan belenggu, yang hendak menegakkan keadilan dan kebenaran! .... Wahai seluruh manusia yang cinta pada tanah airnya, yang ingin supaya bangsanya maju dan tanah airnya mulia! Pakailah kepercayaan, supaya tercapai kemuliaan yang diingini. Kalau tuan-tuan merasai lemah untuk memperbaiki otak angkatan yang sekarang, sebab telah terlalu rusak, perbaikilah otak angkatan yang akan datang, yaitu pemuda-pemuda." ${ }^{3}$

\section{HAMKA Bermuhammadiyah}

Mungkin HAMKA bukan ulama sepenting yang lain dalam Muhammadiyah. Tetapi dia populer dan cukup berpengaruh, justru karena banyak karya tulisnya, yang banyak bicara tentang tasawuf yang ia dekati dari perspektif modern; dan juga persoalan-persoalan etika alias akhlak. Empat buku yang karya pentingnya di bidang keagamaan ditulisnya pada masa di tengah zaman bergejolak, ketika Perang Dunia II sedang berlangsung, yaitu Tasauf Modern (1939), Falsafah Hidup (1939), Lembaga Hidup (1940) dan Lembaga Budi (1940). Tetapi tentu masih banyak karya lain daripada itu, baik berupa fiksi (novel) maupun berbagai ulasan keagamaan yang terpublikasi di majalah Panji Masyarakat. ${ }^{4}$

2 Deliar Noer, "HAMKA dan Sejarah," Membincangkan Tokoh-tokoh Bangsa (Bandung: Mizan, 2001), h. 69.

3 HAMKA, Tasauf Modern (Jakarta: Pustaka Panjimas, 1991), h. 65.

$4 \quad$ Majalah Panji Masyarakat, edisi pertama terbit pada 1959. Majalah ini pernah dibredel oleh rezim Orde Lama (1960-an) karena memuat artikel Bung Hatta bertajuk Demokrasi Kita, yang mengkritisi sistem pemerintahan demokrasi terpimpin Soekarno. Majalah ini terbit kembali paska tumbangnya 
Muhammadiyah adalah organisasi yang hadir di jantung kekuasaan kerajaan Jawa di Yogyakarta, tetapi segera memperoleh sambutan luas, khususnya dari para ulama di Minangkabau - tempat Buya HAMKA berasal. HAMKA, lahir di Kampung Molek, Sungai Batang Maninjau, Kabupaten Agam, Bukittinggi, Sumatera Barat, 17 Februari 1908 (14 Muharram 1326H). Ayahnya Dr. Haji Abdul Karim Amrullah atau Haji Rasul, merupakan ulama pembaharu Minangkabau. Terlepas dari ikhtiar ayahnya mengupayakan HAMKA tertib di sekolah agama, yakni Diniyah School dan Sumatera Thawalib di Padang Panjang dan di Parabek, pada dasarnya HAMKA remaja suka hal-hal yang baru dan berpetualang. HAMKA berkelana ke sejumlah tempat di Minangkabau, sampaisampai ayahnya menjulukinya "Si Bujang Jauh". HAMKA terkesan dengan informasi bahwa Islam di Jawa lebih maju daripada Minangkabau, terutama dalam hal pergerakan dan organisasinya. Inilah yang membuat obsesinya untuk bisa merantu ke Jawa semakin membuncah.

Begitu memperoleh kesempatan, pada 1923, HAMKA berupaya bertolak lagi ke Jawa. Tetapi ketika sampai di Bengkulu, wabah cacar menerpanya. Setelah dua bulan terkapar, HAMKA kembali ke Padang Panjang. Setahun kemudian, setelah sembuh dari cacar, HAMKA kembali nekat merantau ke Jawa, dan kali ini kesampaian: ke Yogyakarta persisnya. Di Yogyakarta HAMKA menetap di rumah adik kandung ayahnya, Ja'far Amrullah, dan melalui pamannya itu, ia mendapat kesempatan mengikuti berbagai diskusi dan pelatihan pergerakan Islam Muhammadiyah dan Sarekat Islam.

Selain terlibat dalam pergerakan Islam, HAMKA juga tertarik pada fenomena kristenisasi dan komunisme. Dalam berbagai kesempatan, HAMKA berguru kepada Ki Bagoes Hadikoesoemo, H.O.S. Tjokroaminoto, H. Fakhruddin, RM. Suryopranoto dan iparnya sendiri, yakni Ahmad Rasyid Sutan Mansur Ketua Muhammadiyah Cabang Pekalongan. Selama di Jawa, HAMKA sempat mengembara ke Bandung dan bertemu beberapa tokoh pergerakan Islam, seperti Ahmad Hassan dan Mohammad Natsir, yang memberinya kesempatan belajar menulis dalam Majalah Pembela Islam. "Sesugguhnya," catat HAMKA dalam bukunya Falsafah Hidup yang dipersembahkannya kepada AR Sutan Mansur;

Orde Lama (1966), dan akhirnya kinerja redaksi benar-benar berhenti pada dekade 1990-an. Namun pada Oktober 2005, majalah Panjimas berdiri dan mengklaim sebagai kelanjutan dari majalah Panji Masyarakat. 
.... adalah beberapa guru yang amat mempengaruhi jalan pikiran saya dalam agama, .... seperti $\mathrm{H}$. Fakhruddin, yang meskipun hanya sekali saja dapat bertemu dengan beliau di kongres Muhammadiyah ke-18 di Solo... K.H. Mas Mansur yang .... mendorong saya buat menyelidiki tarikh Islam. ${ }^{5}$

HAMKA aktif dalam kepengurusan Muhammadiyah cabang Minangkabau, setelah perkawinannya dengan Sitti Raham. Muhammadiyah cabang Minangkabau sendiri cikal bakal dari perkumpulan Sendi Aman yang didirikan ayahnya pada 1925 di Sungai Batang. HAMKA juga sempat menjadi pimpinan Tabligh School yang didirikan Muhammadiyah pada 1930. Sejak menghadiri Muktamar Muhammadiyah di Solo pada 1928, HAMKA tidak pernah absen menghadiri muktamar-muktamar Muhammadiyah berikutnya. Sekembalinya dari Solo, HAMKA mulai memangku beberapa jabatan, sampai akhirnya ia diangkat sebagai Ketua Muhammadiyah Cabang Padang Panjang. Seusai Muktamar Muhammadiyah ke-19 di Bukittinggi pada 1930, disusul dengan muktamar berikutnya di Yogyakarta, HAMKA memenuhi undangan untuk mendirikan Cabang Muhammadiyah di Bengkalis.

Pada 1932, ia diutus Muhammadiyah ke Makassar dalam rangka mempersiapkan dan menggerakkan semangat rakyat untuk menyambut Muktamar Muhammadiyah ke-21. Selama di Makassar, HAMKA sempat menerbitkan AlMahdi, majalah pengetahuan Islam yang terbit sekali sebulan. Pada 1934, setahun setelah menghadiri Muktamar Muhammadiyah di Semarang, HAMKA diangkat menjadi anggota tetap Majelis Konsul Muhammadiyah untuk wilayah Sumatera Tengah. Kariernya di Muhammadiyah semakin menanjak sewaktu ia pindah ke Medan. Pada 1942, bersamaan dengan jatuhnya Hindia-Belanda pada kekuasaan Jepang, HAMKA terpilih sebagai pimpinan Muhammadiyah untuk wilayah Sumatera Timur menggantikan H. Mohammad Said. Namun, pada Desember 1945, ia memutuskan kembali ke Minangkabau dan melepaskan jabatan tersebut.

Pada tahun berikutnya, HAMKA terpilih menjadi Ketua Majelis Pimpinan Muhammadiyah Sumatera Barat menggantikan S.Y. Sutan Mangkuto, hingga tahun 1949. Pada 1953, HAMKA terpilih sebagai pengurus Pimpinan Pusat Muhammadiyah dalam Muktamar Muhammadiyah ke- 32 di Purwokerto. Sejak saat itu, HAMKA selalu terpilih dalam Muktamar Muhammadiyah selanjutnya,

HAMKA, Falsafah Hidup (Kuala Lumpur: Pustaka Antara, 1964), h. 1. 
sampai pada tahun 1971, ia memohon agar tidak dipilih kembali karena merasa uzur. Akan tetapi, ia tetap diangkat sebagai penasihat Pimpinan Pusat Muhammadiyah sampai akhir hayatnya. HAMKA meninggal pada awal Ramadhan 1981, tak berapa lama setelah ia mengundurkan diri dari jabatannya sebagai Ketua Majelis Ulama Indonesia (MUI).

\section{Muhammadiyah Bergerak}

Dalam konteks ini, penulis tidak akan mengulas mengenai prototipe Buya HAMKA sebagai aktivis Muhammadiyah tempo dulu atau berpolemik mengenai karya-karyanya yang sudah menjadi referensi atau bacaan populer khalayak ramai. Namun, sekadar menarik kata "Sendi bangsa ialah budi" sebagai basis pembahasan lebih lanjut tentang agenda gerakan Muhammadiyah dalam mengikhtiarkan Indonesia yang beradab. Istilah "Indonesia yang beradab" dalam wacana Ke-muhammadiyah-an beririsan dengan istilah "masyarakat utama", suatu formasi masyarakat ideal yang berbasis ajaran agama. Landasan dari masyarakat utama sebagai prasyarat untuk memperkokoh Indonesia yang beradab itu, setidaknya merujuk HAMKA di atas, ialah budi.

Menurut Kamus Besar Bahasa Indonesia, budi ialah alat batin yang merupakan paduan akal dan perasaan untuk menimbang baik dan buruk, "tabiat; akhlak; watak"; "perbuatan baik; kebaikan" atau boleh juga kita sebut etika atau moral. ${ }^{6}$ Karena itu, segera dapat dipahami ketika Muhammadiyah dirumuskan sebagai gerakan amar ma'ruf nahy munkar, maka landasan yang dipakai ialah pertimbangan-pertimbangan yang terkait dengan akhlak, yang lantas dirumuskan dalam doktrin-doktrin yang diyakininya - di mana dari sinilah dimensi kontekstualnya mengemuka.

Dalam konteks ini, suatu evaluasi, kalau bukan pengakuan yang cukup obyektif pernah dilontarkan Ketua PP Muhammadiyah 1998-2005, Ahmad Syafii Maarif, bahwa,

"Bila dibandingkan dengan gerakan sosial lainnya di Indonesia, secara kuantitatif, Muhammadiyah dengan segala kelemahannya masih berada di papan atas. Tetapi, apabila parameter yang digunakan adalah cita-cita alQur'an untuk menciptakan sebuah masyarakat Indonesia yang bermoral, Muhammadiyah masih saja berada di jalan awal.”

kbbi.web.id diakses pada 18 Juli 2014.

Ahmad Syafii Maarif, "Kata Pengantar: Muhammadiyah dan Kemerdekaan Berpikir," dalam Abdul Munir Mulkhan, Jejak Pembaruan Sosial Kiai Ahmad Dahlan (Jakarta: Kompas, 2010), h. vii. 
Masih menurut Syafii Maarif, Muhammadiyah yang menyebut dirinya sebagai gerakan dakwah amar ma'ruf nahi munkar, mengisyaratkan tanggung jawab yang besar sekali, "sementara energi Muhammadiyah lebih banyak terkuras oleh kerjakerja sosial kemasyarakatan. Masalah bangsa secara keseluruhan sering tidak sempat terpikirkan secara mendalam." Otokritik yang perlu direnungkan lagi dari Buya, bahwa;

“... di bidang pendidikan dan kesehatan, Muhammadiyah hanyalah sebagai pembantu pemerintah, tidak lebih dan tidak kurang. Muhammadiyah belum mampu menawarkan system alternatif, baik untuk pendidikan, kesehatan, maupun untuk bidang-bidang kemanusiaan lain yang selalu memerlukan perhatian khusus. Jangankan menangani masalah-masalah yang punya cakupan luas itu, mengurus dirinya saja Muhammadiyah sudah kelelahan."

Tetapi Buya juga punya formula, bahwa "Muhammadiyah harus dibaca sebagai gerakan Islam dengan cara kreatif dan kritikal, tetapi tetap berada dalam koridor kepribadian yang telah dirumuskan." Dari formula ini, Muhammadiyah harus bergerak ke arah inklusif, bukan eksklusif. Kreativitas, kritisisme dan halhal lain yang terkait dengan ijtihad keagamaan dan kemasyarakatan, memerlukan suasana yang dialogis, kalau bukan inklusif. Iklim semacam inilah, atau dalam bahasa Buya "kemerdekaan berpikir" harus ditumbuhkan di Muhammadiyah, sebab kalau tidak ia akan statis dan konservatif. Sementara itu, kita juga bisa memaklumi kalimat "koridor kepribadian yang telah dirumuskan" sebagai suatu garis batas kepribadian Muhammadiyah, yang sesungguhnya juga mencerminkan kepribadian universal atau kepribadian Islami yang berkemajuan.

Dalam hal ini, kita bisa menangkap suatu semangat bahwa Muhammadiyah tidak boleh menutup diri dari beragam permasalahan rakyat (umat) dan bangsa. Refleksi dari sikap yang inklusif itu ialah, di tengah realitas pluralisme bangsa, maka Muhammadiyah senantiasa dituntut untuk bisa menempatkan diri dalam kearifan, sehingga tidak mudah terjebak pada polaritas politik yang diametral "kita" dan "mereka".

Politik Muhammadiyah, bagaimanapun adalah politik nilai. Dalam konteks ini, lazim kalau Muhammadiyah, dalam situasi normal dan damai, bersikap independen dalam berbagai urusan yang terkait dengan kontestasi politik. Namun demikian, secara individual, di manapun posisi politik para kadernya, mereka dituntut untuk mampu mewarnai kehidupan politik yang selaras dengan

Ahmad Syafii Maarif, Ibid., viii. 
prinsip-prinsip dasar Muhammadiyah, betapapun ini merupakan hal yang tidak mudah, mengingat politik, menurut Kuntowijoyo, berpotensi miopik. ${ }^{9}$

\section{Dari Muhammadiyah untuk Bangsa}

Membaca dokumen Keputusan Muktamar Satu Abad Muhammadiyah (Muktamar Muhammadiyah ke-46) di Yogyakarta pada 20-25 Rajab 1431 H/3-8 Juli 2010, "Muhammadiyah dan Isu-isu Strategis Keumatan, Kebangsaan, dan Kemanusiaan Universal” yang diterbitkan kembali oleh PP Muhammadiyah, kita melihat bahwa Muhammadiyah bergerak ke arah paradigma yang inklusif. Muhammadiyah mencatat beberapa agenda keumatan, di antaranya; Pertama, terkait dengan kemiskinan kepemimpinan dan keteladanan. Tentu, hal ini berhubungan dengan obyektivikasi di kalangan umat Islam yang seringkali bermasalah dengan ihwal persatuan. Kedua, komodifikasi agama untuk kepentingan bisnis dan politik. Ketiga, konservativisme agama yang tampaknya lebih mengarah ke kritik internal sekaligus eksternal, mengingat yang dimaksud dengan istilah itu adalah kecenderungan untuk mengembalikan praktik keagamaan pada tradisi masa lampau dengan menolak kemajuan.

Yang penting dalam konteks ini adalah penegasan label populer Muhammadiyah yang mengusung paham Islam berkemajuan. Sementara, isu selanjutnya yakni kemajemukan agama dan keadilan gender merupakan dua isu yang selaras dengan perkembangan wacana mutakhir, yang intinya adalah keterbukaan dan sikap adil.

Kemudian, yang terkait dengan isu kebangsaan dicatat ada tujuh, di antaranya: (1) revitalisasi karakter bangsa; (2) pemberantasan korupsi; (3) reformasi lembaga hukum; (4) perlindungan dan kesejahteraan pekerja; (5) sistem suksesi kepemimpinan nasional; (6) reformasi birokrasi; dan (7) reformasi agraria dan kebijakan pertanahan. Beberapa isu tersebut tampaknya merupakan objektivikasi atas permasalahan bangsa yang sering mengemuka, setidaknya menunjukkan bahwa Muhammadiyah tidak ketinggalan zaman dalam mengikuti ragam permasalahan kebangsaan mutakhir.

Demikian pula halnya dengan tujuh isu kemanusiaan universal berikut: (1) krisis kemanusiaan modern; (2) krisis pangan dan energi; (3) krisis ekonomi global; (4) krisis lingkungan dan perubahan iklim; (5) Islamophobia; (6) migrasi global; dan (7) dialog antar-agama dan peradaban.

Kuntowijoyo, Paradigma Islam: Interpretasi untuk Aksi (Bandung: Mizan, 2008), h. 356. 
Sekali lagi, isu-isu inklusif itu menunjukkan bahwa Muhammadiyah semakin menyadari bahwa sebagai bagian penting dari kepemimpinan umat, pihaknya harus responsif terhadap isu-isu aktual, bahkan sejumlah isu yang seolah-olah tidak ada kaitannya dengan keagamaan sekalipun. Hal ini juga penting untuk memecahkan asumsi salah bahwa organisasi semacam Muhammadiyah atau Nahdlatul Ulama (NU) semata-mata hanyalah organisasi yang berurusan dengan tata cara peribadatan keagamaan tertentu; dan karenanya enggan merespons problematika kebangsaan dan global terlalu jauh. Bagaimanapun, Muhammadiyah telah hadir bukan hanya sebagai ormas Islam arus-utama di Indonesia bersama $\mathrm{NU}$; sehingga ia telah menjadi representasi tersendiri khususnya dari segi state of mind keagamaan (Islam Sunni).

Meski semakin kehilangan relevansi, namun masih saja ada sebagian pihak yang suka mengaitkan "cara berislam" Muhammadiyah vis a vis NU - apalagi di era reformasi ini perbedaan penetapan Ramadhan dan Idul Fitri antara Muhammadiyah dan pemerintah (yang menteri agamanya dari unsur NU) sering terjadi. Di masa kini, nyaris tidak lagi ditemukan polarisasi ideologi antara Muhammadiyah dan NU mengingat cairnya panggung politik nasional. Tentu saja, hal yang berbeda dengan era pasca kemerdekaan (1950-an) hingga awal Orde Baru. Umat juga sudah terbiasa dengan perbedaan dan menghormati cara berislam Muhammadiyah atau NU sebagai dua referensi utama keagamaan umat Islam di Indonesia.

Inklusivitas gerakan sosial Muhammadiyah sudah lazim sejak dulu bersifat ulang-alik: Muhammadiyah ada di sekitar elite papan atas kekuasaan, atau setidaknya birokrasi, terutama di kampus-kampus; tetapi juga ada di level masyarakat bawah (grass root), sebagai aktivis tanpa pamrih di level ranting. Tak dimungkiri, jarak wawasan dan pengalaman yang elite dan yang grass root ini seringkali cukup jauh; seringkali memunculkan respons berbeda terhadap masalah tertentu.

Dalam konteks ini, Muhammadiyah sendiri secara organisatoris masih memiliki pekerjaan rumah yang krusial dengan menghidupkan cabang dan ranting, serta memastikan bahwa aspek Islam yang berkemajuan sangat aktual. Meski Muhammadiyah subur dalam amal usaha, namun mengurus wilayah grass root tetap penting dalam kerangka untuk mengimbangi, apa yang disinyalir oleh Moeslim Abdurrahman sebagai proses "memborjuasi” di kalangan Muslim. Ini penting karena watak dasar Muhammadiyah awal adalah menggarap kaum papa 
(dhu'afa), sebagai cermin sebgaimana yang diistilahkan Abdul Munir Mulkhan sebagai etika welas asih K.H. Ahmad Dahlan, yang sering mengulang-ulang Surat Al-Maun.

Etika welas asih dalam perkembangannya memicu, apa yang dipopulerkan oleh Max Weber sebagai "etika Protestan", di mana umat bergerak untuk mandiri secara ekonomi karena hal itu merupakan bagian integral dari ibadah. Tidak mungkin kita menjadi umat yang baik apabila tidak dapat bersedekah sedemikian rupa, karena problem kemiskinan. Justru akar kemiskinan itulah yang harus ditebas. Etos kerja Muhammadiyah, dalam banyak kasus tercermin dengan hadirnya kaum usahawan yang mandiri dan gigih. Tetapi, sebagaimana banyak ulasan, lapisan usahawan itu tergeser oleh kaum birokrat alias pegawai negeri dalam elite Muhammadiyah. Iklim usaha yang tidak kondusif belakangan ini, juga telah membuat lapisan usahawan Muhammadiyah, juga para pengusaha pribumi, tergerus secara signifikan. Ini tentu bukan permasalahan Muhammadiyah saja, tetapi sudah menjadi persoalan bangsa. Mungkinkah Muhammadiyah diam saja? Dalam konteks inilah, diperlukan ikhtiar yang sungguh-sungguh untuk menggerakkan kembali etos kewirausahaan di kalangan Muhammadiyah - yang dalam konteks ini, saya kira perlu belajar dari kesuksesan Turki dalam membangkitkan kelas menengah (Muslim) di sana.

Dalam kerangka membangun Muhammadiyah sebagai gerakan sosial yang inklusif, maka selain harus hati-hati dengan "efek samping" birokratisasi organisasi yang dapat menjebak kepada sikap yang eksklusif, juga harus dibangun suatu komunitas episteme yang inklusif. Secara kualitatif, apabila Muhammadiyah telah menjadi semacam state of mind keagamaan dan kepribadian, maka komunitas intelktual yang inklusif itu, harus menembus batas yang memisahkan Muhammadiyah struktural dengan non struktural. Muhammadiyah yang memang memiliki banyak lembaga pendidikan, benar-benar dimanfaatkan oleh seluruh kader umat dan kader bangsa untuk belajar. Sehingga peradaban Indonesia, antara lain dapat dihadirkan dari Muhammadiyah sebagai rumah ilmu. Terminal bagi banyak kalangan untuk saling berbagi hikmah. Ini merupakan langkah untuk melawan sikap konservatif yang menolak kemajuan.

Tentu dalam mengimplementasikan agenda gerakan untuk Indonesia yang beradab, sesuai dengan tema tulisan ini, Muhammadiyah tidak bisa melangkah maju sendiri. Justru, ia seyogyanya memandu yang lain untuk bersama-sama bergerak maju dalam ikhtiar perbaikan mental dan sistem. Dalam batas-batas 
tertentu, kepemimpinan M. Din Syamsuddin di Muhammadiyah masa kini (2005-2010 dan 2010-2015) telah mengikhtiarkan hal itu. Terlepas dari perkembangan sosial-politik yang melingkupinya (terutama kaitannya dengan demokrasi elektoral dan pasca-pemilu), Muhammadiyah setidaknya bukan hanya suatu entitas yang statis, melainkan tidak segan-segan menjadi terminal bagi beragam anak bangsa yang memiliki keprihatinan terhadap permasalahan bangsa.

Dalam gerakan sosial yang bernuansa gerakan moral (moral force), Muhammadiyah mampu menunjukkan dirinya sebagai entitas yang inklusif dan konsisten pada ikhtiar mewujudkan prinsip demokrasi "checks and balances", tentu bukan dalam konteks kekuatan politik, melainkan suatu gerakan sosial dan civil society yang kreatif. Majelis-majelis ilmu yang digelar di PP Muhammadiyah juga bersifat inklusif, bahkan seringkali Muhammadiyah memelopori gerakan sosial yang melibatkan sejumlah tokoh agama lainnya.

\section{Penutup}

Demikianlah, tradisi inklusif yang dikembangkan oleh Din Syamsuddin pasca-Muktamar ke-46 di Yogyakarta, yang oleh Ahmad Najib Burhani, disebut sebagai "Muktamar Budaya" ini, lebih bermakna positif bagi Muhammadiyah sebagai entitas kepemimpinan umat yang responsif dan partisipatif. Dengan mengembangkan komunitas episteme yang lebih luas (inklusif), maka Muhammadiyah berpeluang untuk menghadirkan nuansa atau warna baru dan segar dalam kehidupan umat dan bangsa.

\section{Bibliografi}

Abdurrrahman, Moeslim, Bersujud di Baitullah, Ibadah haji, Mencari Kesalehan Hidup, Jakarta: Kompas, 2009.

Alfian, M. Alfan, "Seandainya Buya HAMKA Masih Ada," Majalah Amanah, Vol. 54 (7 Mei-7 Juni 2000).

Burhani, Ahmad Najib, "Islam Murni" vs "Islam Progresif" di Muhammadiyah: Melihat Wajah Islam Reformis di Indonesia," Martin van Bruinessen (Ed.) Conservative Turn, Islam Indonesia dalam Ancaman Fundamentalisme, Bandung: Mizan, 2014.

HAMKA, Tasauf Modern, Jakarta: Pustaka Panjimas, 1991.

HAMKA, Falsafah Hidup, Kuala Lumpur: Pustaka Antara, 1964.

Kuntowijoyo, Paradigma Islam: Interpretasi untuk Aksi, Bandung: Mizan, 2008. 
Maarif, Ahmad Syafii, "Kata Pengantar: Muhammadiyah dan Kemerdekaan Berpikir," Dalam Abdul Munir Mulkhan, Jejak Pembaruan Sosial Kiai Ahmad Dahlan, Jakarta: Kompas, 2010.

PP. Muhammadiyah, Muhammadiyah dan Isu-isu Strategis Keumatan, Kebangsaan, dan Kemanusiaan Universal: Keputusan Multamar Satu Abad Muhammadiyah (Muktamar Muhammadiyah ke-46) di Yogyakarta 20-25 Rajab 1431 H/3-8 Juli 2010, Jakarta: PP Muhammadiyah, 2010.

Mulkhan, Abdul Munir, Jejak Pembaruan Sosial Kiai Ahmad Dahlan, Jakarta: Kompas, 2010.

Noer, Deliar, "HAMKA dan Sejarah," Membincangkan Tokoh-tokoh Bangsa, Bandung: Mizan, 2001.

Rahardjo, M. Dawam, Intelektual Inteligensia dan Perilaku Politik Bangsa, Risalah Cendekiawan Muslim, Bandung: Mizan, 1993.

Saidi, Ridwan, Zamrud Khatulistiwa, Jakarta: LSIP, 1993.

Syuja, Kyai, Islam Berkemajuan, Kisah Perjuangan KH Ahmad Dahlan dan Muhammadiyah Masa Awal, Ciputat: Al-Wasath, 2009.

Tamara, Nasir, Hamka di Mata Hati Umat, Jakarta: Sinar Harapan, 1984.

Situs Internet:

kbbi.web.id diakses pada 18 Juli 2014

muhammadiyah.or.id diakses pada 18 Juli 2014

wikipedia.org diakses pada 18 Juli 2014 